\title{
O tema da recepção mediática na bibliografia nacional - uma aproximação inicial
}

\section{Introdução}

Onde se reportar na bibliografia brasileira contemporânea para o estudo do tema da recepção mediática?

As respostas a essa indagação, enquanto indicações bibliográficas possíveis, exigem diferentes considerações prévias. A primeira delas é que se a produção brasileira na área não é incipiente, vem de meados do século no contexto de expansão dos meios de comunicação social e de desenvolvimento do processo urbano-industrial, também é verdade que é uma produção ainda não sistematizada, e como tal é pouco socializada.

Por outro lado, uma segunda consideração fundamental é a que aponta para a necessidade de esclarecer a própria extensão conceitual e, conseqüentemente, teórica do que se entende por recepção mediática. Muito embora se possa entender, numa visão ainda ampla, e voltada para sua dimensão social e política, que este é o campo de estudo das relações sociais, destacando-se em especial o lugar aí desempenhado pela presença mediadora de diferentes meios de comunicação social, o fato é que há hoje pelo menos duas grandes e distintas vertentes de aproximação deste estudo.

De um lado estão aqueles trabalhos voltados à análise dos diferentes impactos comportamentais derivados de influências dos meios de comunicação social, com objetivos mais ligados à configuração de interesses comerciais e mercadológicos do siste- ma produtivo, e, como tais, são estudos voltados ou à audiência de meios de comunicação, ou ao consumo, ou à opinião pública, conforme perspectivas publicitárias, mercadológicas, ou de pesquisa de opinião pública.

De outro lado, na busca de uma visão mais ampla e interdisciplinar da complexidade das relações sociais mediadas pela presença de diferentes meios de comunicação estão os trabalhos acadêmicos, nos quais ganha sentido maior a utilização do termo recepção mediática.

Essas diferentes vertentes não esgotam o estudo do tema, lembrandose que há outras disponíveis (Sousa, 1998), nem se colocam como vertentes que se opõem entre si. Na verdade elas interagem, ao mesmo tempo que não têm limites rígidos constituindo-se no que abarca a expressão vertentes de estudo, ou tradições diferenciadas de estudo a respeito.

Importa salientar que se as produções bibliográficas dessas duas formas diferenciadas de encaminhar o estudo sobre a presença social dos media ganham expressão nos contextos onde são produzidos, e portanto onde mais circulam, é bem verdade ainda que a produção acadêmica, no caso brasileiro, ainda que circule mais no meio que a produz, tem também mais acesso ao grande público através da publicação de livros e de relatórios de pesquisa. E é nessa vertente que estão as produções bibliográficas mais conhecidas, dentro e fora do meio acadêmico, evidentemen- 
te retratando esforços sobretudo derivados de produções de teses e de dissertações de pós-graduados. Também é verdade que as publicações acadêmicas são ainda em quantidade restrita, talvez devido às próprias dificuldades em efetivá-las como publicações. Disso deriva a observação de que as publicações disponíveis nesse campo não podem ser vistas como traduzindo o estágio efetivo do que é produzido: elas são uma parte, ainda que pouco sistematizada de outra, igualmente pouco conhecida, a que se efetiva no âmbito das teses e dissertações universitárias envolvidas em diferentes áreas disciplinares voltadas a seu estudo.

Quando se atém à análise das produções que hoje se colocam disponíveis para o estudo da recepção mediática no país, e apenas àquelas que circulam no meio acadêmico, pelo menos quatro constatações logo se evidenciam: -Primeira: Há que se reconhecer que a temática da recepção mediática não se constitui em campo autônomo de estudos. Ela se vincula à área da teoria da comunicação, envolvendo outros processos e preocupações, entendida ainda como necessariamente vinculada a configurações históricas, sociais e políticas do contexto social de interação entre o quadro sócio-cultural das relações sociais e de expansão e diversificação das tecnologias que lhe dão suporte. Isso vincula, pois, a recepção mediática a um quadro processual de relações sociais, historicamente dadas, e não apenas a veículos de comunicação ou a impactos comportamentais derivados desses mesmos media.

-Segunda: Quando se analisa a bibliografia disponível a respeito no meio acadêmico brasileiro atual percebe-se logo que a produção bibliográfica voltada a essa vinculação teórica, às questões conceituais sobre recepção mediática, ou mesmo aos suportes teóricos de compreensão de suas práticas, são em sua maioria traduções de obras estrangeiras, e ligadas às diferentes posturas teóricas onde a recepção mediática se aloca como componente processual.

Já a bibliografia genuinamente produzida no Brasil, e aqui divulgada, é em sua quase totalidade resultante de trabalhos acadêmicos de dissertações e teses, tomadas públicas em períodos desta segunda metade do século, e quase todos voltados à busca explicativa de diferentes práticas sociais e culturais onde a presença dos meios de comunicação social de alguma forma se configurou como fundamental.

-Terceira: Há diferentes ritmos ou fluxos históricos na produção e publicação desses trabalhos, quer naqueles só traduzidos de obras estrangeiras, mais no âmbito conceitual e teórico, quer naqueles aqui produzidos e publicados. Mas percebe-se que é a partir dos anos 80 que se acentua essa produção/ publicação, no contexto de surgimento de resultados de produções acadêmicas originárias dos cursos de mestrado (anos 60/70) e de doutorado (anos 80) das nossas faculdades e escolas de comunicação social.

-Quarta: Ainda que se possa perceber diferentes tendências de suportes conceituais e teóricos sendo utilizados nos estudos publicados de origem acadêmica brasileira, em sua maioria se reportam aos suportes das teorias fundadoras em comunicação e, só após os anos 80, são voltados à busca de novos paradigmas na sustentação analítica de diferentes práticas de comunicação em desenvolvimento no país.

\section{As questões conceituais e teóricas} nos estudos fundadores (1950-1980)

Miège (1996) entende que o pensamento comunicacional contemporâneo desenvolveu-se na seqüência de três grandes períodos: o primeiro, entre os anos 50/60, propiciou o surgimento das correntes fundadoras em comunicação (o modelo cibernético, o enfoque empírico-funcionalista, o método estruturalista e suas aplicações lingüísticas, o pensamento critico, etc.); o segundo, entre $70 / 80$, foi o período de 
expansão de problemáticas nas quais se destacaram a economia política, a etnografia da comunicação, a recepção das mensagens, a formação de uso dos media etc.; nos dias atuais, dá-se o terceiro período de desenvolvimento do pensamento comunicacional, quando surgem as grandes interrogações sobre as possibilidades de uma teoria geral, novas relações entre informação e comunicação, entre outras questões.

$\mathrm{Na}$ verdade, a bibliografia em comunicação social mais acessível e disponível em português no Brasil atual tem muitos de seus aspectos ligados a essa classificação proposta por Miège, sobretudo na seqüência histórica e na direção teórica seguidas.

Observe-se, por exemplo, que toda a seqüência de compreensão do processo de informação, no modelo cibernético, e toda a derivação desse processo na compreensão da comunicação também como processo social, no modelo empírico-funcionalista, e gerando o que Wolf (1987) denomina de teoria informacional-comunicacional, desenvolveu-se no contexto do füncionalismo norte-americano do início e meados do século. Toda a reflexão funcional-instrumental com que a comunicação foi concebida e a conseqüente percepção da recepção como componente-objeto-instrumento desse processo foi traduzida em obras que se espalharam por todo o mundo. No Brasil, ainda hoje a literatura sobre comunicação de mais fácil acesso continua sendo aquela que foi traduzida para o português, em sua origem norteamericana, entre os anos 60/70, e que alimentou a compreensão não só da comunicação no âmbito mercadológico, mas também os primeiros estudos acadêmicos sobre recepção: os textos de Berlo (1968), Dance (1973), Steinberg (1970), Schramm (1969), entre tantos outros, fartamente acessíveis em português no Brasil, são ainda hoje passíveis de manuseio na configuração histórica de um modelo de ver, não só a comunicação e o seu campo de efeitos comportamentais, como a própria recepção como meta-objeto desses mesmos efeitos. Trabalhos que mais tarde indicavam avanços nessas posturas empírico-funcionalistas através de McLuhan (p. ex. 1969A, 1969B), foram produções bibliográficas que ainda hoje são disponíveis.

É nesse período que começam a surgir coletâneas acadêmicas de textos envolvendo autores diversos, indicando a presença de outras correntes e posturas teóricas, como o pensamento comunicacional a partir dos frankfurtianos, da semiologia, da sociologia e da política, evidenciando não só a pluralidade já emergente no país de posturas explicativas sendo amadurecidas, como uma densidade reflexiva nova, sobretudo proveniente de autores e suportes europeus, em atividades interdisciplinares mais ligadas a questões do estruturalismo social. As coletâneas de Cohn (1969) e Costa Lima (1969), propiciaram essa visão contrastante de enfoques diversos disponíveis para se compreender a comunicação enquanto suporte teórico e especialmente a recepção como seu componente não autônomo.

É bem verdade que no final dos anos 60 e durante boa parte dos anos 70 , a bibliografia disponível em português sobre recepção esteve nas partes e capítulos dos livros que abordavam a comunicação como processo social mais abrangente. $\mathrm{O}$ contexto social e político dos anos 64/ 84 com certeza favoreceu o privilegiamento da dimensão social e política dessa analise, uma visão sociológica muitas vezes hegemônica, depois a antropológica, mas ao que parece sempre sob o prisma do político. Textos como o de Cohn (1973), Swingewood (1978) serviam-se de uma visão sociológica bem diferente daqueles que na década anterior se sustentavam em Merton (1964), na tradição norteamericana, além de outros. Os textos 
originais de Adorno, Horkheimer, Habermas, Benjamin foram sendo definidores para essa visão crítica de comunicação enquanto processo vinculado à estrutura social.

Autores mais contemporâneos como Wolf (1987), Freitag (1986), Sfez (1994), Thompson (1998), com textos que se referem ao significado teórico das posturas fundadoras ou a seus aspectos, acabam sendo referências bibliográficas também para se dizer que desde os anos 50/90 a produção conceitual sobre comunicação tanto quanto sobre recepção ainda é suportada por referências conceituais e teóricas de obras e autores em sua maioria adaptados ou reinterpretados, ressignificados a partir de uma prática cultural do país. Se de um lado, o importante é a autonomia do pensamento que se cria e não suas origens geográficas, também importa reconhecer que esse pensamento comunicacional no Brasil evoluiu em seqüência semelhante ao de outros países mais desenvolvidos.

A partir dos anos 1980, publicações diversas, que começam a surgir no país na área da recepção, passavam a indicar a busca de superação dos suportes explicativos derivados das teorias fundadoras, avançando para o que Miège denominou de época das problemáticas em comunicação. Em um próximo número de Bibliografia Comentada, essa evolução contemporânea será então abordada na possibilidade de elaborações conceituais e teóricas que os anos 80/90 vêm possibilitando em comunicação. Textos de associações e grupos de pesquisa em comunicação, por exemplo da Intercom (Lopes (org), 1997), ou da Compós (Rubim (org), 1998), acentuam essa busca de um novo modo de olhar o processo comunicacional da recepção, e que o texto Sujeito, o lado oculto do receptor introduziu de maneira pioneira no início dos anos 90 (Sousa (org), 1995). No entanto, textos como o de Strasburger (1999) e edições recentes de Berlo (1999) evidenciam que a contribuição empírico-funcionalista igualmente se coloca ainda hoje no cenário de uma sociedade de fim de século, tanto quanto em capítulos da obra de Wolf (1987) é possível aquilatar as perspectivas da proposição sobre a agenda setting, entre outras, como significadoras de uma postura funcionalista em vigor ainda nos dias atuais.

\section{A produção nacional a partir de}

\section{práticas culturais}

Se observado o cenário apontado há pouco sobre o privilegiamento de obras e autores estrangeiros na bibliografia disponível voltada para a conceituação e a teorização em comunicação, e seu campo da recepção, temse uma outra indicação quando se indaga sobre como o processo da recepção tem sido pesquisado e a partir daí sido objeto de reflexão.

É bem verdade que as publicações sobre a temática da recepção, como já apontado anteriormente, vêm refletindo o que pensa a respeito o meio acadêmico do país, mas é também verdade que nem todo pensamento acumulado a respeito está publicado. Trabalhos pioneiros na pesquisa universitária sobre recepção como o de Camargo (1972), talvez a primeira tese de doutorado da área no país, não está publicada. No entanto, em Bosi (1981) temse uma das principais e primeiras referências de pesquisa de recepção quando a autora, após um quadro de sustentação teórica ainda hoje tomado como exemplo, discute, a partir da psicologia social, a leitura de produtos mediáticos feito por operárias (a tese é de 1972). O texto-tese de Da Viá (1977) é outro exemplo de produção pioneira na área da recepção. $\mathrm{O}$ mesmo se refere ao hoje clássico trabalho de Miceli (1972), quer pelo seu objeto de estudo, quer pela sua estratégia teórico-metodológica de suporte.

E percebe-se então que é nos anos 80 que as publicações começam a mostrar não só rupturas, questiona- 
mentos e novas buscas de olhares interpretativos, entrando no que Miège classifica de problemáticas, muitas delas tomadas em sua dimensão interdisciplinar de análise, como nos trabalhos de Sarques (1986) e Pacheco (1985), ampliando aspectos psicológicos da recepção associados a questões culturais.

Talvez se possa dizer que as teses publicadas por Lins da Silva (1986) e Leal (1986) expressem sobretudo a busca de alternativas dos suportes explicativos de recepção no domínio da cultura, especialmente quanto aos estudos culturais (no caso de Lins da Silva).

É a direção que conseguiu também Fisher (1984) ao associar a problemática da comunicação à educação e cultura, e Goldfeder (1980), sobre público radiofônico e ideologia.

De qualquer forma, é no final dos anos 80 que as publicações nacionais se ampliam, e passam a tomar a direção crítica não mais apenas de confirmação de grandes paradigmas como no período de influência mais acentuada das posturas fundadoras do pensamento comunicacional.

Trabalhos outros publicados na confluência da temática da recepção associada a questões sociais (p. ex. Lopes, 1988eNeto, 1989) indicam essa ampliação do quadro reflexivo no país no que se refere a uma visão renovada do processo da comunicação, sobretudo a partir dos estudos culturais ingleses em sua versão ressignificada na América Latina contemporânea, tema para uma próxima Bibliografia Comentada.

Assim, mais indicativa do que comentada de fato, mais descritiva do que propriamente analítica, a presente Bibliografia Comentada se introduz no esforço de trabalhar a temática da recepção mais do que apenas obras e autores isolados.

\section{Bibliografia Indicada}

Baptista, Maria Luiza Cardinale - Comunicação, trama de desejos e espelhos. Ed. ULBRA, Canoas, RS, 1996.

- Berlo, David - O processo da comunicação. Ed. Fundo de Cultura, Rio de Janeiro, 1968.

- Berlo, David - O processo da comunicação. Livraria Martins Fontes editora Ltda, São Paulo, 1999.

- Bosi, Ecléa - Leituras operárias. Ed. Vozes, Petrópolis, 1984.

Camargo, Nelly de - A TV e o quadro de referência sócio-cultural - o público dos telepostos de São Luiz. Tese Doutorado, ECA/USP, São Paulo, 1972.

- Castells, M. - A sociedade em rede. Ed. Paz e Terra, São Paulo, 1999.

- Cohn, G. - Comunicação e Indústria Cultural. CEN/EDUSP, São Paulo, 1971.

- Cohn, G. - Sociologia da comunicação. Ed. Pioneira, São Paulo, 1973.

- Da Viá, Sara Chucid - TV e consciência de classe. Ed. Vozes, Petrópolis, 1981.

- Dance, F. E. X. (org.) - Teoria da comunicação humana. Ed. Cultrix, São Paulo, 1973.

- Fischer, Rosa Maria Bueno - O mito da sala de jantar. Ed. Movimento, Porto Alegre, 1984.

- Freitag, B. - A teoria crítica, ontem e hoje. Ed. Brasiliense, São Paulo, 1986.

- Goldfeder, M. Por trás das ondas da Rádio Nacional, Ed. Paz e Terra, Rio de Janeiro, 1980

- Leal, Ondina Fachel - A leitura social da novela das oito. Ed. Vozes, Petrópolis, 1986.

- Lima, Luis Costa - Teoria da cultura de massa. Ed. Saga, Rio de Janeiro, 1969.

- Lins da Silva, Carlos Eduardo - Muito além do Jardim Botânico. Summus Ed., São Paulo, 1985.

-Lopes, M. I. V. (org.) - Temas contemporâneos em comunicação. Edicom/ Intercom, São Paulo, 1997.

- Lopes, M. I. V. - O rádio dos pobres. Ed. Loyola, São Paulo, 1988.

- Marcondes Filho, Ciro - A linguagem da sedução. Ed. ComArte, ECAUSP, São Paulo, 1986. 
- McLuham, M. e Fiore, Q. - O meio são as massagens. Ed. Record, Rio de Janeiro, 1969.

- McLuham, M. - Os meios de comunicação como extensão do homem. Ed. Cultrix, São Paulo, 1969.

- Merton, Robert K. - Teoria y estrutura sociales. Ed. Fundo de Cultura Economica, México, 1964.

- Miceli, Sérgio - A noite da madrinha, Ed. Perspectiva, São Paulo, 1972.

-Miège, B. - El pensamiento comunicacional. Univ. Iberoamericana, México, 1996.

- Neto, Antonio Fausto - Mortes em derrapagem. Ed. Rio Fundo, Rio de Janeiro, 1989.

-Pacheco, Elza Dias - O pica-pau: Herói ou vilão?: representação social da criança e reprodução da ideologia dominante. Ed. Loyola, São Paulo, 1985.

- Pye, Lucien W. - Comunicações e desenvolvimento político. Ed. Zahar, Rio de Janeiro, 1967.

- Rubim, A. Albino e outros (org.) - Produção e recepção dos sentidos midiáticos. Ed. Vozes, Petrópolis, 1998.

- Sarques, Jane Jorge - A ideologia sexual dos gigantes, Ed. UFG, Goiânia, 1986.

- Schramm, W. e outros - Panorama da comunicação coletiva. Ed. Fundo de Cultura, Rio de Janeiro, 1984.

- Sfez, Lucien - Crítica da Comunicação. Ed. Loyola, São Paulo, 1994.

- Sousa, M. W. (org.) - Sujeito, o lado oculto do receptor. Ed. Brasiliense, São Paulo, 1995.

- Sousa, M. W. - A recepção sendo reinterpretada. Revista Novos Olhares, $\mathrm{N}^{\circ} 1,1998$, p. 39.

- Steinberg, C. (org.) - Meios de comunicação de massa. Ed. Cultrix, São Paulo, 1970.

-Strasburger, Victor - Os adolescentes e a Mídia. Ed. Artmed, Porto Alegre, 1999.

- Swingewood, A. - O mito da cultura de massa. Ed. Interciência, Rio de Janeiro, 1978.

- Thompson, John B. - A mídia e a modernidade. Ed. Vozes, Petrópolis, 1998.

-Wolf, M. - Teorias da Comunicação. Ed. Presença, Lisboa, 1987.

-Zilberman, Regina - Estética da recepção e história da literatura. Ed. Ática, São Paulo, 1989. 